\title{
Photovoltaic installation for a roofed car park in Egypt as an example of effective use of solar energy
}

\author{
Michał Wichliński ${ }^{1, *}$, Janusz Staszkiewicz ${ }^{1,2}$ \\ ${ }^{1}$ Czestochowa University of Technology, Faculty of Infrastructure and Environment, Energy \\ Engineering Department, 42-200 Częstochowa, Poland \\ ${ }^{2}$ Solar Shams, 71 Syria Street (P.O. Box 140) Mohandessin, Cairo 12411, Egypt
}

\begin{abstract}
Photovoltaic installations are becoming an increasingly important player in the global renewable energy production market. The biggest disadvantage of photovoltaic installations is their high price, and relatively low efficiency. Photovoltaic cells achieve a theoretical efficiency of $30 \%$, but in real conditions this efficiency is much lower at roughly $15 \%$. Photovoltaic installations are particularly recommended in locations where the amount of solar radiation is high and where photovoltaic installations will be able to work at full capacity for most of the year. The paper presents an analysis of the work of a photovoltaic installation built for a roofed car park located in eastern Cairo, the capital of Egypt. The installation is built for a car park located at the Schlumberger company. The installation is built of 1344 Hanwha Q.Power L-G325 silicon polycrystalline cell modules, each module has a power of $325 \mathrm{Wp}$, and the total area of the installation is $2,611 \mathrm{~m}^{2}$. Effective irradiance on collectors is $1922 \mathrm{kWh} / \mathrm{m}^{2}$. The array's nominal produced energy was $840 \mathrm{MWh} /$ year, the amount of electricity injected into the grid was $587 \mathrm{MWh} /$ year, which means that the calculated performance ratio was 0.62 .
\end{abstract}

\section{Introduction}

Renewable energy is currently a very dynamically developing field of the economy. 2016 was the year in which there was more than a 50\% growth in installed solar installations in the world, year by year. In 2016, the total power of installed solar installations was over $76.6 \mathrm{GW}$. Since 2011, the number of photovoltaic installations has increased by more than $36.6 \mathrm{GW}$ [1]. The largest market for solar energy was China, where in $201634.5 \mathrm{GW}$ were connected, which means an increase of over $120 \%$ compared to 2015 (15.1 GW) [2]. The second largest market was the United States, where in $201614.8 \mathrm{GW}$ were installed, an increase of $97 \%$ compared to 2015 ( $7.5 \mathrm{GW})$. The third place was Japan with $6.7 \mathrm{GW}$ of connected solar installations. The European Union was only in fourth place at $6.7 \mathrm{GW}$, which means a decrease by $21 \%$ compared to 2015 (8.6 GW) [1]. Among the

*Corresponding author: michal.wichlinski@gmail.com 
EU countries, the largest market for solar installations was Germany (over 38,000 MW), Italy (over 18,800 MW) and the United Kingdom (over 5,200 MW). According to one of the scenarios for the development of the photovoltaic (PV) installation after 2017, the total number of installed PV installations in 2021 will be about $105.7 \mathrm{GW}[1,3]$. The rapid development of the PV installation is also associated with a significant reduction in the cost of electricity production from this type of installation. Within two years (from April 2015 to February 2017), the average price of electricity from solar installations in Germany decreased by more than $28 \%$ (from 9.2 eurocents $/ \mathrm{kWh}$ to 6.6 eurocents $/ \mathrm{kWh}$ ) [1].

Particularly intense development of solar energy takes place in countries where climate conditions favours such investments. Such countries are the countries of North Africa and the Middle East. One of these countries is Egypt. Demand for electricity in Egypt is steadily growing and in the years 1985-2016 it has increased from $30 \mathrm{TWh}$ to over $180 \mathrm{TWh}$. The growth rate of electricity consumption was high and amounted to around $3.4 \%$ in 2005-2015, and in 2016 it was already 4.7\%.However, most of Egypt's electricity is produced from non-renewable fuels, especially from oil and gas. This is primarily due to the proximity of the Middle East countries, which have a huge resource of these fuels. The share of renewable energy sources in the total production of electricity is small, it mainly consists of hydroelectric power plants. The share of solar installations is very small and does not exceed 2.6 TWh [4,5]. However, the weather conditions prevailing in Egypt predestine this country for the development of these types of installations. The average number of sunny hours per year is 3,451 , the shortest day of the year lasts $10 \mathrm{~h}: 03 \mathrm{~min}$, and the longest $13 \mathrm{~h}: 56 \mathrm{~min}[6,7]$. The number of sunny hours during the day is over $78 \%$. The average amount of solar radiation reaching the surface of the earth varies from 5.4 to $7.1 \mathrm{kWh} / \mathrm{m}^{2}$. The estimated annual solar radiation potential is about 74 billion $\mathrm{MWh} / \mathrm{year}$ and many times exceeds the demand of Egypt for electricity [3, 7]. According to Ibrahim [5], in 2004-2005, approximately $26.5 \mathrm{~kW}$ of PV installations were installed in Egypt every year [8]. Most of them were low power installations used in communication (32\%), advertising lighting (24\%), and in lighting (20\%). The aim of this article was to describe the presentation of an effective photovoltaic installation and compare its parameters with other such installations.

\section{Description of photovoltaic installation}

This article presents the PV power plant which was installed as a roof of car park. This car park is located in the east part of Cairo, at Schlumberger company (Fig.1). One of the authors was the assistant project manager at Solar Shams in Cairo. His tasks were analysing the actual energy production from the installation and assisting in creating the operation and maintenance plan for the location. The installation began work at the end of 2017, the article presents the design assumptions of the installation. After a full year we will be able to assess how these assessments have been confirmed in real conditions. 

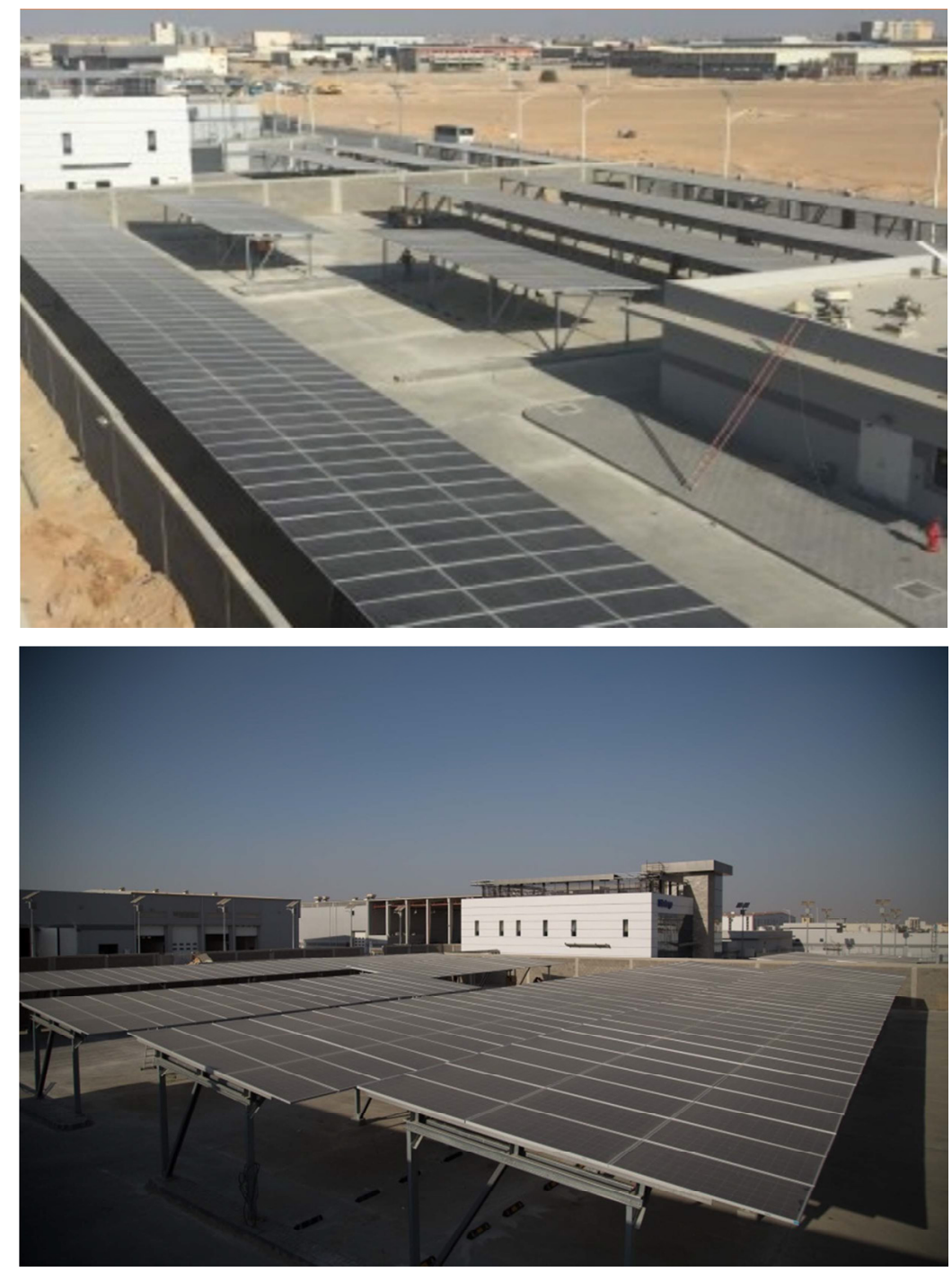

Fig. 1. PV installation for roofed car park at Schlumberger company.

The grid connected park consists of 1,344 polycrystalline silicon solar modules, Hanwha Q.POWER L-G5 325, $325 \mathrm{Wp}$ each. Technical data of PV module are given in Table 1. Overall installed capacity of $437 \mathrm{kWp}$ covering a total surface area of $2,355 \mathrm{~m}^{2}$. The installation is inclined at $45^{\circ}$ toward the south and inclined at an angle $5^{\circ}$. The PV modules are arranged in 14 parallel strings with 96 modules in each string. Each strings are connected to a $25 \mathrm{~kW}$ inverter Schneider Electric model Conext CL 25000E feeding directly into the grid. Technical data of inverter are given in Table 2. The main $\mathrm{PV}$ installation parameters are given in Table 3. 
Table 1. PV module speciation in STC and NOCT conditions [9].

\begin{tabular}{|c|c|}
\hline PV module & Specification \\
\hline Model & Q.POWER L-G5 325 \\
\hline Power at MPP at STC* conditions & $325 \mathrm{~W}$ \\
\hline Current at MPP at STC conditions & $8.67 \mathrm{~A}$ \\
\hline Voltage at MPP at STC conditions & $37.5 \mathrm{~V}$ \\
\hline Efficiency & $16.74 \%$ \\
\hline Power at MPP at NOCT** conditions & $239 \mathrm{~W}$ \\
\hline Current at MPP at NOCT conditions & $6.93 \mathrm{~A}$ \\
\hline Voltage at MPP at NOCT conditions & $34.5 \mathrm{~V}$ \\
\hline
\end{tabular}

* - STC - Standard Test Condition;

** - NOCT -Normal Operating Cell Temperature

Table 2. Inverter speciation [10].

\begin{tabular}{|c|c|}
\hline Inverter & Specification \\
\hline Model & Conext CL 25000E \\
\hline Unit nominal power & $25 \mathrm{kWac}$ \\
\hline Operating voltage & $430-800 \mathrm{~V}$ \\
\hline Numbers of inverters & 14 units \\
\hline Total power & $3,650 \mathrm{kWac}$ \\
\hline
\end{tabular}

Table 3. Main PV system parameters [11].

\begin{tabular}{|c|c|}
\hline Main system parameters & Specification \\
\hline System type & Grid-connected \\
\hline PV field orientation tilt & $5^{\circ}$ \\
\hline Number of modules & 1,344 \\
\hline Array global power at STC conditions & $437 \mathrm{~kW}$ \\
\hline Array global power at operating conditions $\left(50^{\circ} \mathrm{C}\right)$ & $393 \mathrm{kWp}$ \\
\hline Array operating characteristic $\mathrm{U}_{\mathrm{mpp}}$ & $537 \mathrm{~V}$ \\
\hline Array operating characteristic $\mathrm{I}_{\mathrm{mpp}}$ & $732 \mathrm{~A}$ \\
\hline Module area & $2,611 \mathrm{~m}^{2}$ \\
\hline Cell area & $2,355 \mathrm{~m}^{2}$ \\
\hline
\end{tabular}

\section{Results and discussion}

The photovoltaic system used for this study is installed as a car park roof in 6th of October City near Cairo with a latitude $29.95^{\circ} \mathrm{N}$ and longitude $30.90^{\circ} \mathrm{E}$ and about 149 meters above the sea level. The horizontal global irradiation for the localization of PV installation was from $93.9 \mathrm{kWh} / \mathrm{m}^{2}$ (in December) to 252.2 (in June). During the whole year the horizontal irradiation was $2112.5 \mathrm{kWh} / \mathrm{m}^{2}$, horizontal diffuse irradiation was about $25-30 \%$ of horizontal irradiation -and the yearly total was roughly $500 \mathrm{kWh} / \mathrm{m}^{2}$. Average ambient temperature in PV installation localization was $22^{\circ} \mathrm{C}$ (Table 4). Effective energy at the output of the array was total 632.69 MWh and it varies from 33.04 MWh in December to 68.42 MWh in July. Energy injected into the grid was roughly 8\% less than effective energy at the output of the array, in total it was $587.45 \mathrm{MWh}$. Performance ratio (PR) for the whole year was 0.62 , and it was varying from 0.597 in June and July to 0.727 in January and 0.726 in December (Fig.2). Lower PR in summer months was caused by weather conditions as ambient temperature and horizontal global irradiation. In summer in Cairo temperature can achieve over $38^{\circ} \mathrm{C}$ [6], the PV cells are tested in STC conditions 
$\left(20^{\circ} \mathrm{C}\right)$ and NOCT conditions $\left(25^{\circ} \mathrm{C}\right)$, the lack of efficiency for Si-poly cells are $0.41 \%$ per ${ }^{\circ} \mathrm{C}$ above $25^{\circ} \mathrm{C}$ [24]. The lack can also be caused by the covering of PV modules by a layer of speck and dust. Performance ratio was calculated from equation (1) [12].

$$
P R=\frac{Y_{f}}{Y_{r}}[-]
$$

where:

$\mathrm{Y}_{\mathrm{f}}$ - Final yield, defined as total AC energy during a specific period divided by the rated power of the installation $[\mathrm{kWh} / \mathrm{kWp} /$ day],

$\mathrm{Y}_{\mathrm{r}}$ - Reference yield, is the ratio of the global solar radiation and the PV`s reference irradiance $[\mathrm{kWh} / \mathrm{kWp} /$ day].

Performance ratio in similar localization in North Africa adduced by Attari et al. [12] (Tangier, Morocco $35,75^{\circ} \mathrm{N}, 8,34^{\circ} \mathrm{W}$ ) was form 0.58 in December to 0.98 in January. Total Performance ratio for the whole year was 0.79 . For other PV installations the Performance ratio varies from 0.7 to 0.9 (Thailand) [13], from 0.38 to 0.88 (Germany) [14], and from 0.5 to 0.8 (Poland) [15].

Table 4. Balance and main results for tilt $5^{\circ}$ in Cairo [11].

\begin{tabular}{|c|c|c|c|c|c|c|c|c|}
\hline \multirow{2}{*}{ Month } & \multirow{2}{*}{ GlobHor } & DiffHor & T Amb & GlobInc & GlobEff & EArray & E_Grid & PR \\
\cline { 2 - 9 } & $\mathrm{kWh} / \mathrm{m}^{2}$ & $\mathrm{kWh} / \mathrm{m}^{2}$ & ${ }^{\circ} \mathrm{C}$ & $\mathrm{kWh} / \mathrm{m}^{2}$ & $\mathrm{kWh} / \mathrm{m}^{2}$ & $\mathrm{MWh}$ & $\mathrm{MWh}$ & {$[-]$} \\
\hline January & 102.3 & 32.90 & 13.60 & 109.8 & 96.4 & 36.05 & 34.88 & 0.727 \\
\hline February & 120.4 & 35.00 & 14.30 & 126.7 & 111.9 & 40.51 & 39.12 & 0.707 \\
\hline March & 173.3 & 45.60 & 17.10 & 179.7 & 159.3 & 54.91 & 52.90 & 0.674 \\
\hline April & 204.6 & 49.20 & 21.70 & 208.3 & 184.8 & 60.66 & 58.38 & 0.642 \\
\hline May & 237.2 & 53.60 & 25.20 & 238.1 & 211.7 & 66.90 & 64.28 & 0.618 \\
\hline June & 252.2 & 46.50 & 27.90 & 250.8 & 223.5 & 68.20 & 65.44 & 0.597 \\
\hline July & 251.7 & 49.00 & 29.50 & 251.7 & 224.2 & 68.42 & 65.65 & 0.597 \\
\hline August & 232.5 & 45.30 & 29.40 & 235.0 & 208.8 & 64.52 & 62.01 & 0.604 \\
\hline September & 191.4 & 40.20 & 27.40 & 196.5 & 174.2 & 55.79 & 44.41 & 0.517 \\
\hline October & 148.8 & 39.40 & 23.40 & 156.1 & 138.2 & 47.33 & 38.21 & 0.560 \\
\hline November & 107.1 & 33.00 & 19.10 & 114.4 & 100.9 & 36.34 & 30.20 & 0.604 \\
\hline December & 93.9 & 30.70 & 14.89 & 100.8 & 88.5 & 33.04 & 31.96 & 0.726 \\
\hline Year & 2115.2 & 500.40 & 22.00 & 2168.0 & 1922.5 & 632.69 & 587.45 & 0.620 \\
\hline
\end{tabular}

GlobHor - Horizontal global irradiation,

DiffHor - Horizontal diffuse irradiation,

$\mathrm{T}$ Amb - Ambient Temperature,

GlobInc - Global incident in coll. Plane,

GlobEff - Effective Global, corr. for IAM and shadings,

EArray - Effective energy at the output of the array,

E_Grid - Energy injected into grid,

$\mathrm{P} \overline{\mathrm{R}}$ - Performance Ratio. 


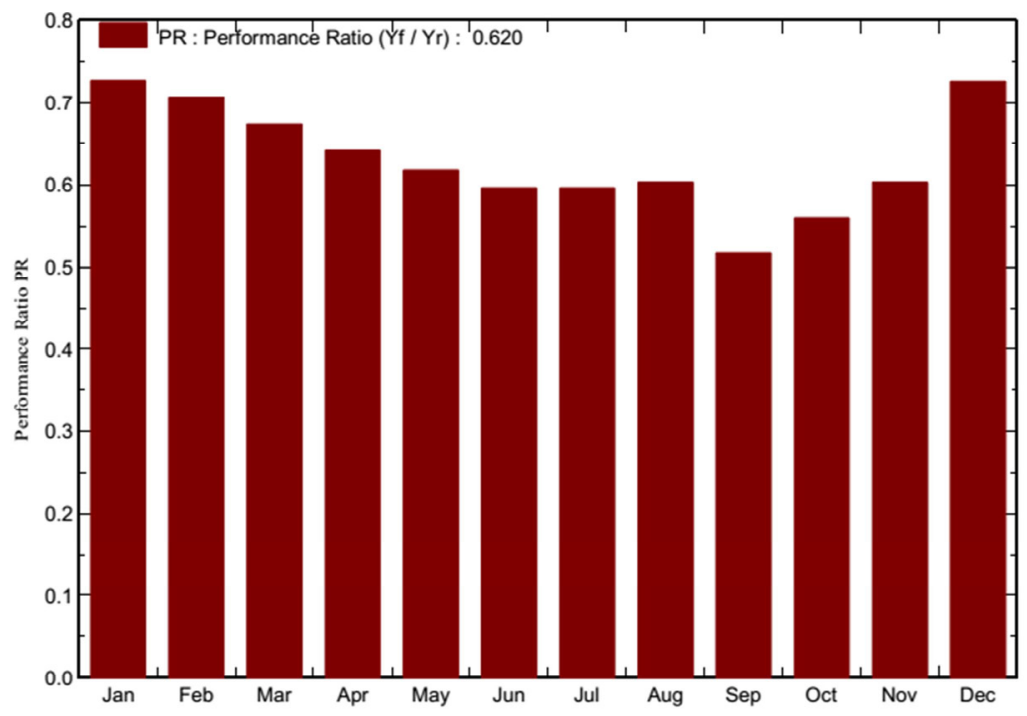

Fig. 2. Performance ratio [11].

Comparison of various PR for different PV installation were shown in Fig 3. For the most of selected installations performance ratios were above 0.7 . The highest PR was for Morocco $5 \mathrm{kWp}$ installation 0.79 [12]. The lowest performance ratios were for India 1816 $\mathrm{kWp}$ installation [27] - 0.637, and for present in this article Egypt PV installation - 0.62.



Fig. 3.Comparison of $\mathrm{PR}$ for selected $\mathrm{PV}$ installations, according literature data [12,16, 23, 25-27]. 
The installation average monthly final yield was shown in Fig. 4. On this figure also shown are the collection and system losses over the mentioned period. The average system losses were $0.28 \mathrm{kWh} / \mathrm{kWp} /$ day, the biggest system losses were in September, October, and November. The average collection losses were $1.97 \mathrm{kWh} / \mathrm{kWp} /$ day, the biggest losses were between April and September. Such big losses in summer period might be due to soiling, dust and lack of maintenance during these months. Attari et al. [12] reported that for mentioned Tangier installation system losses were between 0.14 (January) to 1.89 (May) $\mathrm{kWh} / \mathrm{kWp}$. Capture losses were varying from $0.025 \mathrm{kWh} / \mathrm{kWp}$ in February to $0.76 \mathrm{kWh} / \mathrm{kWp}$ in September. The final yield, defined as production of the useful energy, vary from $2.2 \mathrm{kWh} / \mathrm{kWp}$ during winter months (November-January), to roughly 5.0 during summer months (May-August).

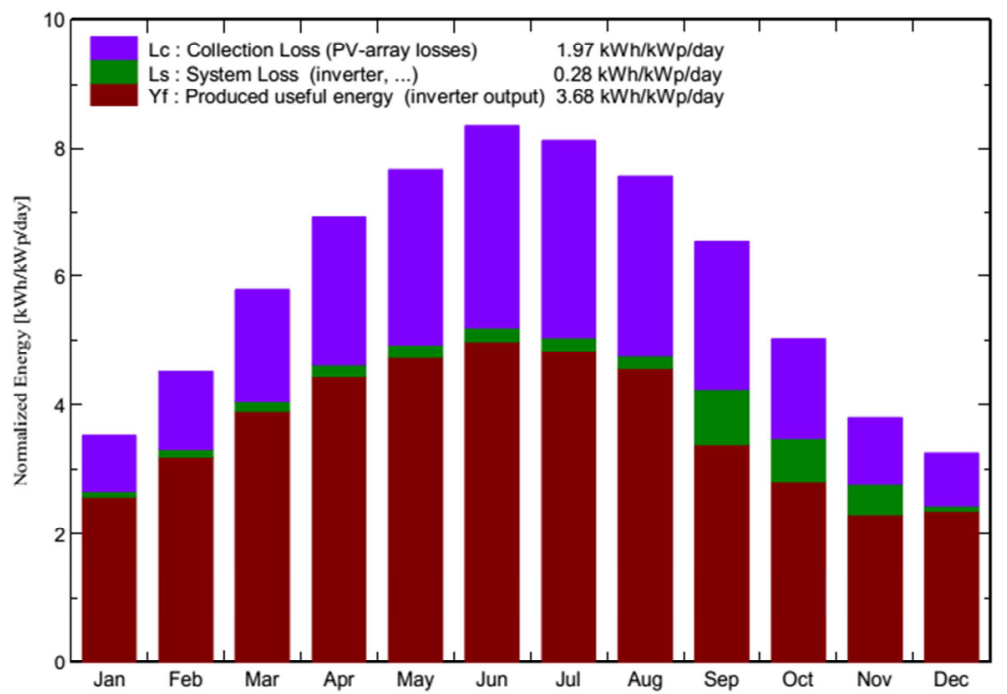

Fig. 4. Installation final yield and corresponding capture and system losses per month [11].

Figure 5 shows final yield comparison of PV installation in different counties. The highest final yield was achieved by installation located in Oman $(5.1 \mathrm{kWh} / \mathrm{kWp} /$ day $)$ [21], also very high final yield was for PV installation located in Kuwait $(4.5 \mathrm{kWh} / \mathrm{kWp} /$ day) [22] and Morocco (4.4 kWh/kWp/day) [12]. The PV installation's final yield presented in this article was $3.7 \mathrm{kWh} / \mathrm{kWp} /$ day, which was on the same level as in India $(3.8 \mathrm{kWh} / \mathrm{kWp} /$ day) [17] and Spain (3.8 kWh/kWp/day) [20] and higher than in other localizations.

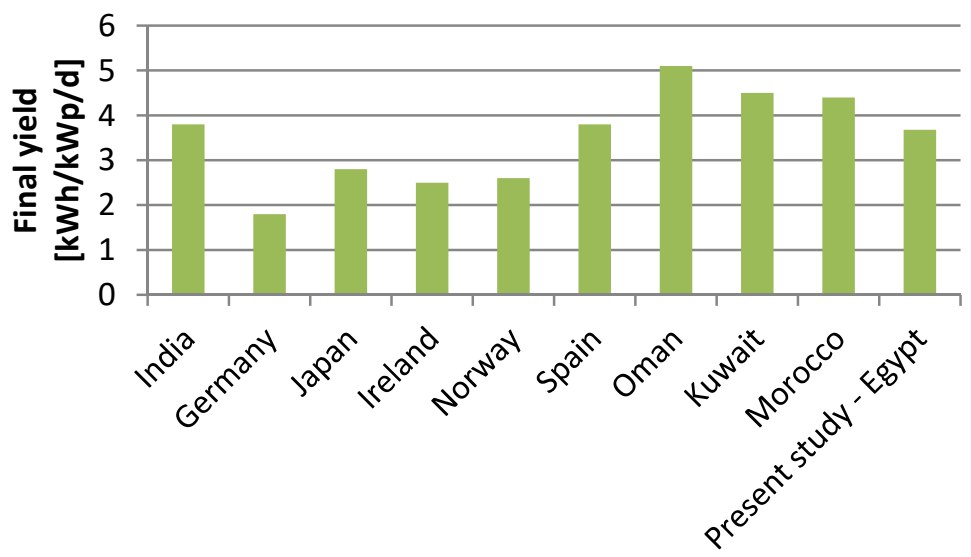

Fig. 5. Comparison of final yield for selected PV installation,according literature data [12, 14, 17 -22]. 
The annual losses from the installation were shown in the Fig. 6. The biggest losses were caused by soiling factor (about 10\%), and ohmic wiring (about 16.3\%). Also, losses caused due to temperature were high (about 7.3\%). Much smaller were losses caused by light induced degradation (2.0\%), and inverter loss during operation (2.2\%). The losses for the presented installation were very similar to those presented in the previously mentioned publication Attari et al. [12]. For their Morocco PV installation PV degradation losses were high $(5 \%)$, but other losses were particularly the same: temperature losses $(7.2 \%)$, soiling losses $(8.75 \%)$, inverter losses $(5.43 \%)$. The highest losses were, similar to the Egypt PV installation, ohmic wiring losses (16\%). Shiva Kumar and Sudhakar presented a loss diagram for an $10 \mathrm{MW}$ PV installation in India, in that case the biggest were losses caused by temperature (10.7\%), irradiance level (3.1\%), and soiling losses (2.1\%) [23].



Fig. 6. Diagram of estimated losses in the PV system [11].

\section{Conclusion}

In this paper was showed a PV installation which was localized in Egypt. The PV installation was made by Si-poly modules, and the total module area was $2611 \mathrm{~m}^{2}$. Module efficiency at STC conditions was $16.74 \%$. This installation was able to produce about $587 \mathrm{MWh}$ of energy into the grid per year. Average annual final yield achieved was about $3.7 \mathrm{kWh} / \mathrm{kWp}$, which was lower than the installation from Morocco or Oman, but similar to 
installations in India and Spain. Average annual performance ratio was 0.62, the lowest was on September 0.517 , the highest was on January (0.727) and December (0.726). Total losses for this installation were roughly $30 \%$, over half of them were caused by ohmic wiring $(16.3 \%)$.

The research was financed by grants No.BS/PB-404-301/11

\section{References}

1. M. Schmela, Global Market Outlook for Solar Power 2017-2021, SolarPower Europe, Belgium (2017)

2. M.-I. Hou, D.-W. Zhang, Energy Policy 51, 38-45 (2012)

3. L. Dusonchet, E. Telaretti, Renewable and Sustainable Energy Reviews 42, 986-998 (2015)

4. B. Dudley, BP Energy Outlook (2017)

5. A. Ibrahim, Renewable and Sustainable Energy Reviews 16, 216-230 (2012)

6. http://www.cairo.climatemps.com/sunlight.php, access 23.04.2108

7. M.A. Mosalam Shaltout, M.Y.T. Tadros, Renewable Energy, 4, 387-393 (1994)

8. K.D. Patlitzianas, Renewable Energy, 36, 2305-2311 (2011)

9. Q.Power L-G5 315-335 Poly crystalline Solar Module, Hanwha, Q-Cells Co. Ltd. (2017)

10. Schneider Electric, (Conext CL 25000E, Installation and operation manual, 2015)

11. Solar Shams, Energy Rep., 2, 261-266 (2016)

12. S. Chokmaviroja, R. Wattanapong, Y. Suchart, Renew. Energy 31, 19-28 (2006)

13. U. Jahn, W. Nasse, Prog. Photovolt. Res. Appl. 12, 441-448(2004)

14. S.M. Pietruszko, M. Gradzki, Opto-Electron Rev. 12 (1), 91-93 (2004)

15. A.K. Shukla, K. Sudhakar, P. Baredar, Energy Rep., 2, 82-88 (2016)

16. K. Padmavathi, S. Daniel, Energy Sustainable Dev. 17, 615-625 (2013)

17. L.M. Ayompe, A. Duffy, S.J. McCormack, M. Conlon, Energy Convers. Manage. 52, 816-825 (2011)

18. M. Adaramola, E. Vagnes, Energy Convers. Manage. 90, 458-465 (2015)

19. C.M. Sidrach, L.L. Mora, Energy 24, 93-102 (1999)

20. H. Kazem, T. Khatib, K. Sopian, W. Elmenreich, Energy Build. 82, 123-129 (2014)

21. A. Al-Otaibi, Energy Convers. Manage. 95, 110-119 (2015)

22. B. Shiva Kumar, K. Sudhakar, Energy Rep., 1, 184-192 (2015)

23. B. Szymański, Instalacje fotowoltaiczne, GLOBEnergia (2017)

24. S.K. Yadav, U. Bajpal, Energy for Sustainable Development 43, 130-138 (2018)

25. R. Sharma, S. Goel, Energy Rep., 3, 76-84 (2017)

26. K.S.S. Pundir, N. Varshney, G.K. Singh, Comparative study of performance of grid connected solar photovoltaic power system in IIT Roorkee campus, (Proc. of int conf on innovative trends in science, eng. and manag. New Delhi, 2016) 